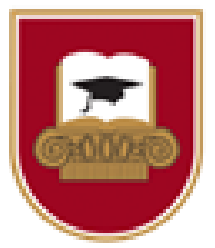

\title{
OPPORTUNITIES OF THE CRM CONCEPT IN CREATING PROCESS OF A VALUE-BASED TOURISM PRODUCT
}

\author{
Deimena Kiyak ${ }^{\mathbf{1}}$, Daiva Labanauskaite ${ }^{2}$ \\ Lithuania Business University of Applied Sciences ${ }^{1}$, Siauliai State College ${ }^{2}$
}

\begin{abstract}
The modern tourism is to combine with new trends in customer behaviour and new expectations. The consumer of tourism services has evolved from being a rational, thinking of the future to an emotional consumer with big needs, dreaming of a "good life". There is a shift from lower-class consumption habits to higher-class consumption. The modern tourist is expecting a personalized offer of a tourism product. It is a big challenge for the providers of tourism services to offer a tourism product as a "commodity of experience", which is acquired by those who transform their experiences into memories and build on them for further decisions. The problem of the scientific discussion in this is article is concentrated on the theoretical opportunities to customize CRM tools in the in the value creating process of a tourism product offered by small tourism service providers. The aim of the article is to identify benefits and risks of a CRM concept in creating process of a value-based personalized tourism product offered by small tourism service companies.

The scientific literature describes CRM in various ways - as a business philosophy (building a customer-oriented culture and building long-term customer relationships), as a business strategy (functional plans and actions to build customer relationships) and as a technological tool (using information technology for data collection, analysis and customisation through customer relationship management). CRM is also described as a method that requires software and technology that automates the company's business processes related to sales, marketing and customer service. Increasing access to information systems and falling prices for computer programs improve customer relationships in today's travel industry. From a strategic perspective, CRM is an organisational process that enables a company to measure customer's margin and manage customer relationships, thereby improving the company's profitability. Using information technology solutions and building a customer information base simplifies the customer relationship management process.

CRM as a new described as a new management mechanism to improve corporate-customer relationships that can be applied as technical support in the marketing, service and other customer-related areas of the tourism business so that customers always feel supported by service personnel and business will keep abreast of changes in customer needs. This encourages tourism companies to make the most of its available resources for customer interaction and to achieve management of travel choices from tourist flows, marketing and technical support, and mutual evaluation management.

Tourism companies should develop data collection technique, as this technique can help them develop marketing strategies and maximise the organisation's profits. Tourism companies should collect huge amounts of customer data that can be integrated into databases and are used to make marketing decisions about them. Tourism companies can monitor customer purchasing behaviour by using the submitted process to analyse the data collected. This helps tourism companies personalise marketing solutions and offers to match the preferences of different customers. Tourism companies can maintain regular customers, stop the transition of the most profitable customers to competitors, classify their preferences and influence the prices of short-term services, thereby optimising profitability.

In the tourism product development process, the aim is to strengthen user orientation, thus increasing the value of the tourist product for the consumer, the CRM application can be seen as a strategic use of customer data by integrating them into the loyalty scheme, using information technology. Improvement programmes of organisations are constantly evolving, taking into account the new possibilities of information technology in business processes, which can also be attributed to CRM. Proper use of information technology can help maintain customers through more efficient customer relationship management, based on knowledge and strong interaction.

KEY WORDS: tourism; CRM concept; value-based tourism product; creating of tourism product; opportunities of the CRM concept.
\end{abstract}

\section{Introduction}

Relevance of the topic. The modern tourism is to combine with new trends in customer behaviour and new expectations. The consumer of tourism services has evolved from being a rational, thinking of the future to an emotional consumer with big needs, dreaming of a "good life". There is a shift from lower-class consumption habits to higher-class consumption. When buying everyday consumer goods, the consumer tends to save. On the other hand, consumers want to emphasise their social status, which is why consumption becomes demonstrative. Thanks to e-commerce, the consumption space is expanding from the local market to the global. Consumption increases when there is an opportunity to purchase goods or services in instalments. Surrounding people make a significant influence on consumption. Exchanges between countries, cultures and individuals around the world intensify and drive the development of global culture. In terms of the behaviour of tourism consumers, it has been found that the "consumption for consumption" has been replaced by the philosophy of "consumption for experiencing". The new tourist is described as educated, experienced and with much higher expectations than ever before. With the help of technology, he knows a lot and is able to adapt to different cultural environments. As a result, the number of self-planned trips is growing and e-tourism is gaining in popularity.

The problem statement. The topic of application of the CRM concept in the service business has been 
discussed quite extensively in the research of scholars of different countries. When it comes to the application of CRM tools in the tourism business, they are being used more by larger businesses - hotel chains, airlines, travel agencies. However, today's tourist is prioritizing a niche tourism product offered by smaller tourism providers. This means that small tourism companies also need to look for CRM principles in their operations. The modern tourist is expecting a personalized offer of a tourism product. It is a big challenge for the providers of tourism services to offer a tourism product as a "commodity of experience", which is acquired by those who transform their experiences into memories and build on them for further decisions. The problem of the scientific discussion in this is article is concentrated on the theoretical opportunities to customize CRM tools in the in the value creating process of a tourism product offered by small tourism service providers.

The aim of the article: to identify benefits and risks of a CRM concept in creating process of a value-based tourism product offered by small tourism service companies.

The object of the research: assumptions, benefits and risks of a CRM concept.

\section{The objectives:}

- To uncover the relationship between the CRM concept and the relationship management.

- To identify benefits of the CRM concept for small tourism companies.

- To analyse risk factors impacting the success of the CRM concept in the creating process of a value-based tourism product.

Methods of the research: induction, comparative analysis and synthesis of partial knowledge.

The paper is organized as follows. The first subchapter introduces the assumptions of the CRM customizing in tourism business, the second subchapter presents expression of the CRM benefit in the tourism business, the third subchapter discusses the CRM in the tourism product value creation process.

\section{Assumptions of the CRM customizing in tourism business}

Due to rapidly changing technological innovations, growing customer needs, intensified competition and changes in the distribution system of tourism, the tourism sector, and in particular travel agencies, have been operating under difficult conditions in recent years (Prause et al. 2011). In addition, one of the key functions of travel agencies is to act as a consultant who takes care of the highest level of customer interaction. In order to maintain long-term relationships with customers, it is important that reciprocal communication and a climate of confidence prevail in the mutual relationship (Prause et al. 2011).

Changes in the tourism market and the importance of the content of the emotional tourism product value have created preconditions for the application of the relationship marketing tools in the tourist business. The rapid development of information technology has diminished the role of the intermediary function in the tourism business, with the simultaneous intensifying the position of the user as an active operator in the development of the tourism product. Technological progress has also led to intensified competition as potential market coverage and sphere of influence have increased, prompting companies to look for other ways to gain competitive advantage (Damkuvienè et al. 2007). Over the past decades, the number of better educated and demanding consumers who are looking for goods and services tailored to their specific needs, has been growing (Harker et al. 2006). The necessity to understand rapidly the changing patterns of customer behaviour and to create a value offer that meets the structure of user needs has prompted organisations to develop collaborative relationships based on cooperation (Damkuvienè et. al. 2007). It has become increasingly clear that for companies, the focus on production, service or sales is no longer sufficient to remain competitive, and that it is essential to dedicate their efforts on building, maintaining and strengthening long-term customer relationships and connections.

Although the majority of relationship marketing activities in the tourism business are customer-oriented to strengthen competitiveness, business-to-business relationships remain significant. In the context of competition for consumer choice moving towards qualitative content, it becomes essential to ensure the integrity of the tourism product generated by different tourism service providers in terms of the transfer of quality and value to the consumer. S. Baron et al. (2010), referring to Möller and Halinen (2000), relates this to market-based marketing (customer-centric marketing) and network-based marketing.

S. Dibb et al. (2004) cited by Chaffey et al. (2000), who argues that relationship marketing theory provides a conceptual framework for personalised marketing, which emphasises service delivery to the customer based on customer information and the focus on segmenting markets at the individual level. Direct marketing in tourism business provides opportunities to tailor the marketing communication and the tourism product structure to a specific client. The transaction marketing paradigm prevailed in the

R. Žvirelienè et al. (2008), I. Skačkauskienė et al. (2011) highlighted the key dimensions of relationship marketing that influence the development of successful relationships with consumers and other stakeholders: commitment, trust, communication, satisfaction, collaboration, empathy, guarantees, conflict management, consumer admiration, engagement, intent, loyalty (2008) notes that commitment and trust are the cornerstones of relationship marketing, while other elements are linked to trust and commitment. Summarising the relationship marketing modelling her research, I. Skačkauskienè et al. (2011) highlight the main objective areas of relationship marketing: consumer satisfaction, consumer admiration, engagement and intent, and consumer loyalty. Relationship marketing tools (direct marketing, data marketing, quality management, service marketing and customer collaboration) that are focused on the abovementioned areas are selected to build and maintain a relationship of trust and empathy between consumers and businesses. 
With its functional influence in the tourism business, relationship marketing is close to customer relationship management. Some authors (Baron et al. 2010) assume that the terms "relationship marketing" and "customer relationship management" (CRM) are largely identical, but most authors (Kim et al. 2012, Milovic 2012, Bahrami et. al. 2012; Rababah et. al. 2011) analyse CRM as a stand-alone concept, formed from relationship marketing. The focus of relationship marketing and customer relationship management concepts is long-term individual relationships between the company and customers for the benefit of both sides. Highlighting the differences between these concepts, it is argued that relationship marketing is strategy-related and that customer relationship management is more tactical in nature. Also, the concept of relationship marketing is more about emotions and behaviours as it focuses on feelings: commitment, empathy, reciprocity and trust. Meanwhile, the CRM concept focuses on efforts to attract, retain and strengthen customer relationships, and is therefore considered more of a management level (Rababah et al. 2011). Both lines of business are important as alternative forms of tourism become more popular, with the tourism product development focusing on the target market segment, as well as offering niche tourism products or exclusive travel to the market.

\section{Expression of the CRM benefit in the tourism business}

The scientific literature describes CRM in various ways - as a business philosophy (building a customeroriented culture and building long-term customer relationships), as a business strategy (functional plans and actions to build customer relationships) and as a technological tool (using information technology for data collection, analysis and customisation through customer relationship management) (Rababah et al. 2011, Pedron et al. 2009). It is noteworthy that from a scientific point of view, the emphasis is placed on philosophical rather than technological CRM content. Kh. Rababah et al. (2011) summarised the CRM content analysis of C. D. Pedron et al. (2009) by stating that CRM as a philosophy is at the heart of any strategy and application of information technology, where philosophy is implemented by strategies intended to drive IT application.

CRM is also described as a method that requires software and technology that automates the company's business processes related to sales, marketing and customer service. Increasing access to information systems and falling prices for computer programs improve customer relationships in today's travel industry. From a strategic perspective, CRM is an organisational process that enables a company to measure customer's margin and manage customer relationships, thereby improving the company's profitability. Using information technology solutions and building a customer information base simplifies the customer relationship management (CRM) process (Fan 2008).

M. Wei (2010) describes CRM as a new management mechanism to improve corporate-customer relationships that can be applied as technical support in the marketing, service and other customer-related areas of the tourism business so that customers always feel supported by service personnel and business will keep abreast of changes in customer needs. This encourages the travel agency to make the most of its available resources for customer interaction and to achieve management of travel choices from tourist flows, marketing and technical support, and mutual evaluation management.

In response to growing turbulence, a competitive and complex environment in the market and technology, relationship marketing based on customer relationship management (CRM) often becomes a strategy for tourism companies and marketing orientation (Prause et al. 2011). Travel agencies and other tourism companies were among the first to apply online marketing in their business and CRM. F. L. Lin et al. (2012) argue that customer data is essential in the tourism business. Travel agency managers use customer information to personalise promotional offers to target customers. Long-term customers cost organisations less and increase purchases because they are less likely to encounter problems and have fewer needs. In order to cope with changing consumer demand, travel agencies need to focus on market segmentation through CRM, thereby enhancing marketing and tourism product management. And IT can help improve CRM performance. As a result, CRM technology application can help organisations achieve all operational goals (Lin et al. 2012).

Although researchers provide different definitions of customer relationship management, the most commonly cited components that form the core of CRM can be identified. According to M. Almotairi (2009), CRM consists of three components: technology, people and business process. R. Jasilionienè et al. (2006) and H. Tohidi et al. (2012) provides a slightly different composition of CRM components. According to the authors, the key components of CRM are customer, relationship and management. The CRM concept emphasises the compliance with Paret's rule according to which $80 \%$ of the company's revenue comes from $20 \%$ of customers. These clients should receive more attention, time and money investment than others, as attracting new clients is five times more expensive than retaining existing ones (Aizcorbe 2007). CRM can help select the most beneficial customers for your business. The data collected about customers becomes knowledge that results in a company's profits, but the company's activities can only be based on this knowledge when the data is processed and the decisions taken on the basis of it attract or retain customers (Urbanskienè et al., 2008).

R. Urbanskienè et al. (2008) highlights the benefits of CRM systems for business owners, employees, and customers:

- Higher profits achieved are the main benefits for the owners of CRM systems:

- Customer benefits of CRM systems: the possibility to receive offers in the appropriate form, when necessary and needed, to be properly serviced, to feel important, informed in time, the possibility to choose a service method (selfservice, full service).

- Benefits of CRM systems for employees: the system helps to perform more activities at the same time, which involves higher salaries; a 
sense of self-control, the possibility to show oneself as a leader and present it as an advantage of excellence.

According to J. Pai et. al. (2011), the benefits of using CRM not only help a company reach a profitable market (or a business opportunity), but it also improves the competitive advantage of price reductions and the acquisition of a higher customer value compared to competitors. However, a truly successful CRM should integrate information technology (such as software, systems, etc.), information resources (such as customer databases, vendor interview records, good customer interaction, etc.) as well as organisational resources (such as customer-centric business culture, etc.); all of which can actually help to achieve the best performance (Pai et al. 2011). CRM implementation enhances the company's operations: brings more opportunities to build and maintain customer relationships, develop loyalty, customer segmentation, grow and measure customer satisfaction and value, more efficient management of information, communication and direct marketing, improve services, and reduce operating costs.

People, customer management and thorough evaluation are the most critical elements of success in the tourism business. In order for these elements to interact, a CRM implementation integrates a sales, marketing and service strategy that coordinates all aspects of customer exchanges with the primary goal of building relationships in providing (2012) stated that CRM is customer-focused and creates unique value by tailoring service to customer needs, promoting company commitments and increasing customer satisfaction and loyalty. CRM provides customer behavioural perception, on the basis of which companies differentiate and personalize their products. Sh. Wu et al. (2012) cites Sigala (2005) who states that successful CRM implementation requires management and integration of three management processes: information technology, relationships (internal and external) and knowledge management. As a result, CRM integrates internal and external company activities to enhance customer relationships and achieve company goals (Wu et al. 2012).

Ž. Karazijienè et. al. (2013) highlighted issues that can be addressed through CRM systems:

- The customer database does not allow any customer to be forgotten;

- Customer segmentation allows you to conduct personalised marketing and make an offer for each segment;

- Aggregated data provides an opportunity to analyse customer behaviour and tailor various loyalty programs to relevant customers;

- The system collects information about clients and any decisions affecting an individual (in the case of legal entities). Thus when any staff changes occur, all customer contacts remain in the company

- The system collects all customer requests and complaints, which can be used to initiate changes within the company.

The CRM management system integrates the concept of customer relationship management and the latest IT technologies as essential tools to help travel agents achieve their customer-focused management goal. In order to promote customer satisfaction, travel agencies need to have full control over customer information, accurately understand customer preferences, respond promptly to their individual needs, provide a convenient point of purchase, and engage with customer after he delivery of the service. Thus, the CRM system is a unified model for managing different relationships between travel agencies and their customers, designed to acquire new customers, maintain current ones, and conduct the customer performance analysis (Lei 2012).

CRM systems help tourism companies optimise customer resources and enhance their value. They can adapt information technology to analyse customers' past spending habits, purchasing opportunities and assess the degree of creditworthiness in order to offer more customer-oriented information to customers and related tourism companies. The ability of these systems to track the service stages and to carry out a detailed analysis of information facilitates the one-to-one relationship securitised by travel agencies with tourists and business partners. For these reasons, tourism companies can more expeditiously offer related products and services (crosssales), improve the degree of customer satisfaction, increase their benefits and find new profit growth points. In addition, this system allows different types of marketing to be adapted to different tourists, i.e. to offer more services and better prices to important intermediaries, which can play an important role in stabilising customer resources.

\section{CRM in the tourism product value creation process: consistency and risk factors}

P. Lei (2012), using the value chain of Michael Porter, analysed the application of the CRM system at the travel agency management level. The CRM value chain includes the analysis of CRM systems in different types of travel agencies in terms of operational strategy, traveller understanding and analysis, and network-based customer relationships. By analysing traveller data, tourism companies distinguish between customers or groups of customers with a perception of value and try to learn as much about them as possible in order to provide a personalised service that will not only promote mutually beneficial relationships between travel agencies, but also help to strengthen customer relations management.

To determine the benefits of customer relationship management for the tourism business, customer relationship management in the hotel sector was analysed. According to P. Lei (2012), the main success factors in the tourism business are not only the quality of the product or service, but also the relationship with customers. High levels of customer satisfaction and good relationships are key sources of profit and performance. This means that retaining customers by increasing their satisfaction and loyalty is a crucial factor in hotel development. Following this approach, a twodimensional CRM model was presented, distinguishing: customer relationship planning that focuses on customer relationships and a customer interaction system consisting of customer relationship tools. 
Despite the listed benefits of using CRM systems, research shows that many companies that have implemented CRM systems have not achieved the benefits they expected. C. D. Pedron et al. (2009), referring to C. D. Payne (2006), states that:

- 69 per cent CRM projects have little impact on sales results;

- company managers consider their CRM projects to be significantly less successful than those of their competitors or suppliers;

- 70 per cent CRM initiatives fail in the next 18 months;

- 60 per cent CRM projects end in failure.

- To explain the reasons for these statistics, C. D. Pedron et al. (2009) and M. Almotairi (2009) distinguished the assumptions that led to a decrease in CRM utility:

- CRM only as a perception of technology;

- lack of skills in developing and using new CRM systems; short time of preparation process; exclusion of the end CRM user in CRM formation issues; insufficient CRM skills;

- insufficient investment, as many projects significantly exceed the planned costs and sometimes even the scope of application;

- poor data quality and quantity, mainly in the early stages of CRM development; low quality data; difficulties associated with obtaining and integrating data have not been assessed;

- inability to grasp the benefits for business: many executives realise only the high cost of implementing CRM and are unable to understand the potential financial benefits;

- $\quad$ lack of management support; lack of leadership and senior management involvement;

- inadequate measuring systems: sometimes organisations do not know what they expect from a CRM implementation;

- underestimation of long-term customer value;

- cultural problems - many organisations need to change their core strategy (vision, goals, etc.) to become a customer-oriented organisation; lack of a customer-centred culture; lack of vision and strategy; lack of customer-focused vision; the need for change in the organization.

- ineffective change management; underestimation of the importance of change management; inadequate reorganization of business processes.

M. Almotairi (2009), quotes Rigby (2002), who states that the main cause of CRM failure is the lack of a proper CRM development strategy. The researcher highlighted four risks of CRM implementation that need to be addressed:

1) Implementation of CRM before the development of a customer-oriented strategy;

2) CRM application before organisational changes;

3) the belief that the more CRM technologies the better;

4) consumer persecution instead of attracting them to their side. (Almotairi 2009).
Recognising the prerequisite for CRM application success is the integration of marketing and sales functions. If there is no link between marketing and sales, then sales themselves must collect information about customers and the sales will run again other activities that have already been carried out by the marketing department. In the absence of a link between the service and marketing departments, the marketing department spends a lot of time to determine the purpose of the product, consumption scenarios, which leads to a longer marketing planning process and reduces its effectiveness. Finally, if there is no connection between sales and service, the planning of the service work and forecasting of future contracts is more complicated (Erglis 2011).

Ch. Liu and X. Zhu (2009) distinguishes four CRM dimensions that indicate the consistency of the CRM process:

1) identification of customers. The CRM process begins with customer identification, also known as customer acquisition. This phase includes the exclusion of potential customers, the most useful groups of customers, and the analysis of lost customers and the search for opportunities to recover them.

2) attracting customers. By identifying potential customer segments, organisations can focus their efforts and resources on attracting targeted customers. A key element in attracting customers is direct marketing, which is defined as a process of promotion that motivates customers through various channels to purchase a product.

3) customer retention is a core goal of CRM. Customer satisfaction, as a result of meeting the expectations of customers and the perception of the benefits actually received, is a prerequisite for maintaining customers. Customer retention items include one-to-one marketing, loyalty programs and complaint management. Personal marketing prioritises personalised marketing campaigns based on customer behavioural analysis, identification and change prediction.

4) customer development. Customer development elements include customer lifetime value and analysis, cross-sales and market basket analysis. Cross-sales refers to promotional activities aimed at expanding into the company's goods or services used by customers, the number of similar and related goods or services.

T. Lin et al. (2012) provided a 4-step process for data collection that is commonplace and useful for the tourism business:

Step 1: Customer data collection. At this stage, tourism companies can discover other valuable customer information through their orders and membership registration processes. This information includes special preferences, the type of accommodation one wants and the duration of the trip, which can help tourism businesses modify their marketing campaigns and increase bookings.

Step 2: Classification of customer data collected. Tourism companies can analyse demographic information 
that divides customers into segments that relate to customer purchases and needs.

Step 3: Identification of target segments. Identifies customer groups with similar behaviour, measures customer response to different offers, creates long-term relationships with customers.

Step 4: Improvement of services. High-profitability customers can be maintained by data collection tools that allow to personalise services according to the preferences of each customer.

Tourism companies should develop data collection technique, as this technique can help them develop marketing strategies and maximise the organisation's profits. Tourism companies should collect huge amounts of customer data that can be integrated into databases and are used to make marketing decisions about them. Travel agencies can monitor customer purchasing behaviour by using the submitted process to analyse the data collected. This helps tourism companies personalise marketing solutions and offers to match the preferences of different customers. Tourism companies can maintain regular customers, stop the transition of the most profitable customers to competitors, classify their preferences and influence the prices of short-term services, thereby optimising profitability (Lin et al. 2012).

In the tourism product development process, the aim is to strengthen user orientation, thus increasing the value of the tourist product for the consumer, the CRM application can be seen as a strategic use of customer data by integrating them into the loyalty scheme, using information technology. Improvement programmes of organisations are constantly evolving, taking into account the new possibilities of information technology in business processes, which can also be attributed to CRM. Proper use of information technology can help maintain customers through more efficient customer relationship management, based on knowledge and strong interaction.

\section{Conclusions}

CRM is usually analysed as a stand-alone concept, formed from relationship marketing. Highlighting the differences between these concepts, it is argued that relationship marketing is strategy-related and that customer relationship management is more tactical in nature. Also, the concept of relationship marketing is more about emotions and behaviours as it focuses on feelings: commitment, empathy, reciprocity and trust. Meanwhile, the CRM concept focuses on efforts to attract, retain and strengthen customer relationships, and is therefore considered more of a management level.

The benefits of using CRM not only help a company reach a profitable market (or a business opportunity), but it also improves the competitive advantage of price reductions and the acquisition of a higher customer value compared to competitors. CRM implementation enhances the company's operations: brings more opportunities to build and maintain customer relationships, develop loyalty, customer segmentation, grow and measure customer satisfaction and value, more efficient management of information, communication and direct marketing, improve services, and reduce operating costs.
Main risk factors impacting the success of the CRM concept in the creating process of a value-based tourism product is accompanied by business decision errors such as skill shortages, underinvestment, poor data quality and quantity, inability to understand business benefits, lack of management support, inadequate measurement systems, lack of long-term customer value perception, cultural issues, ineffective change management . In turn, the key to the success of CRM application is the integration of marketing and sales functions.

\section{References}

Aizcorbe, A. C. (2007). Customer Relationship Management (CRM) as an innovative Element of direct Marketing and its Impact in Market Performance. A Strategy to Personalize Market Massification Creating a Change in the Culture of Management with the Client: a Focus to increase Company Profitability through the Development of Customer Loyalty and Knowledge. International Business \& Economics Research Journal, No. 6, p. 7-18.

Almotairi, M. A (2009). Framework for successful CRM Implementation. European and Meditaterranean Conference on Information Systems, UK, No 14, p. 1-14.

Bahrami, M., Ghorbani, M. (2012). Information Technology (IT) as An Improvement Tool For Customer Relationship Management (CRM). International Conference on Leadership, Technology and Innovation Management. Procedia - Social and Behavioral Sciences, No. 41, p. 5964.

Baron, S., Conway, T., Warnaby, G. (2010) Relationship Marketing: A Consumer Experience Approach. The public house California.

Damkuvienè, M., Virvilaitè, R. (2007). The Concept of Relationship Marketing Theory: Definitions and theoretical Approach. Ekonomika ir Vadyba, No. 12, p. 318-325.

Dibb, S., Simkin, L., (2008). Marketing Planning. London: Cengage Learning.

Erglis, A., Mickevica, S. (2011). Critical Success Factors of Customer Relationship Management Process Adoption in Latvian IT Enterprises. Organizaciju vadyba: sisteminiai tyrimai, No. 59, p. 55-67.

Fan, Y. (2008). Key Perspectives in Nation Image: Conceptual Framework for Nation Branding. Brunel Business School.

Jasilionienè, R., Tamošiūnienè, R. (2008). Ryšių su klientais valdymo sistemų investicijų efektyvumo vertinimas: investicijų grąžos metodo taikymo teoriniai ir praktiniai aspektai. Verslas: teorija ir praktika, No. 9 (3), p. 221-228.

Karazijienè, Ž., Sabonienè, A. (2013). Customer Relationship management systems'prevalence in Lithuanian business. Economics and Management, No. 18 (1), p. 49-57.

Kim, M., Park, J. E. (2012). Frequency of CRM implementation activities: a customer-centric view. Journal of Services Marketing, No. 26/2, p. 83-93.

Lei, P. (2012). The Designing and Implement of CRM System for Travel Industry. The $7^{\text {th }}$ International Conference on Computer Science \& Education proceedings. Melbourne, Australia, p. 1252-1255.

Lin, F. L., Yang, W. G., Lu, K. S. (2012) Construct the destination image formation model of Macao: the case of Taiwan tourists to Macao. Tourism and Hospitality Management, No. 18, p. 19-35.

Liu, Ch.; Zhu, X. (2009). A study on CRM technology implementation and application practices. International Conference on Computational Intelligence and Natural Computing. 2009, No. 1, p. 367-370.

Milovic, B. (2012). Application of CRM Strategy. International Conference on Technology and Business Management, No. 1, p. 106-110. 
Pai, J., Tu, F. (2011). The acceptance and use of customer relationship management (CRM) systems: An empirical study of distribution service industry in Taiwan. Expert Systems with Applications, No. 38, p. 579-584.

Pedron, C. D., Saccol A. Z. (2009). What Lies behind the Concept of Customer Relationship Management? Discussing the Essence of CRM through a Phenomenological Approach. BAR, Curitiba. No. 6, p. 3449.

Prause, G.; Mandez, M. M. (2011). Attitudinal loyalty and trust in entrepreneurship: building new relationships.

Entrepreneurial Manager Journal, No 9, p. 531-540.

Rababah, Kh.; Mohd, H. (2011). A Unified Definition of CRM towards the Successful Adoption and Implementation. Academic Research International, Vol. 1, Issue 1, p. 220 228

Skačkauskienè, I., Tropovaitè, K. (2011). Ryšių marketingo kaip vartotojų lojalumą formuojančio veiksnio tyrimas. Contemporary Issues in Business, Management and Education'2011, Vilnius, "Technika”, p. 264-276.
Tohidi, H., Jabbari, M. M. (2012). CRM as a Marketing Attitude Based on Customer's Information. Procedia Technology. 2012, No. 1, p. $565-569$.

Urbanskienè, R., Žostautienè, D., Chreptavičienè, V. (2008). The Model of Creation of Customer Relationship Management (CRM) System. Engineering Economics, No. 3 (58), p. 51-59.

Žvirelienè, R., Bučiūnienè, I. (2008). Santykių marketingo dimensijų vaidmuo išlaikant vartotojus. Verslas: teorija ir praktika No. 9(4), p. 272-280.

Wei, M. A (2010). Researh on Marketing Management Information System for Travel Agency based on CRM. Proceedings of the $29^{\text {th }}$ Chinese Control Conference, p. 259-254.

Wu, Sh.; Chen, J. (2012). Comparison between hotels and motels using CRM effect model - An empirical study in Taiwan. International Journal of Hospitality Management, No. 31, p. 1254-1263.

Daiva Labanauskaite, doctor of social sciences (04S), Siauliai state college, associated professor. Assoc. Prof. Dr. Daiva Labanauskaite is a team member and research manager of different scientific and applied researches in international tourism. She is author of over 40 scientific publications, of a monograph, among those many papers are related to the service economy and tourism. She has a lot of practical experience in international tourism, experience in different international tourism projects as "Improvement of Entrepreneurial Skills in a Multicultural Environment", "From Local to Global" etc., was a team member and research manager of different scientific and applied researches, is a co-author of the educational standard for the education of hotel managers. Adress: Aušros al. 40, LT-76241 Šiauliai, phone: +370 686 42862, E-mail: d.labanauskaite@svako.lt

Deimena Kiyak, doctor of social sciences (04S), Lithuania Business University of Applied Sciences, associated professor. Adress: Turgaus 21, Klaipeda, phone: +370 68220253. E-mail: deimena.kiyak@gmail.com 
